\title{
Multidrug resistant P-glycoprotein positive L1210/VCR cells are also cross-resistant to cisplatin via a mechanism distinct from P-glycoprotein-mediated drug efflux activity
}

\author{
Lenka Gibalová1, Ján Sedlák², Martina Labudová ${ }^{3}$, Miroslav Barančík ${ }^{1,4}$, Alena Reháková1, \\ Albert Breier ${ }^{1}$ and Zdena Sulová ${ }^{1}$ \\ ${ }^{1}$ Institute of Molecular Physiology and Genetics, Centre of Excellence of the Slovak Research and Development Agency \\ „BIOMEMBRANES 2008”, Vlárska 5, 833 34, Bratislava, Slovakia \\ ${ }^{2}$ Cancer Research Institute, Slovak Academy of Sciences, Vlárska 7, 83391 Bratislava, Slovakia \\ ${ }^{3}$ Institute of Virology, Slovak Academy of Sciences, Dúbravská cesta 9, 84005 Bratislava, Slovakia \\ ${ }^{4}$ Institute for Heart Research, Centre of Excellence for Cardiovascular Research, Slovak Academy of Sciences, Dúbravská \\ cesta 9, 84245 Bratislava, Slovakia
}

\begin{abstract}
P-glycoprotein (P-gp, a drug transporter found in the plasma membrane)-mediated multidrug resistance of leukemia cells represents a real obstacle in the effective chemotherapeutic treatment of leukemia. While cisplatin ( $\mathrm{CisPt}$ ) is known to be a substance that is untransportable by P-gp, P-gp positive cells were often found to be resistant to CisPt.

The aim of the current paper is to study this phenomenon using P-gp positive mouse leukemia cells L1210/VCR in which the overexpression of P-gp was induced by its ability to adapt to growth on vincristine (VCR).

L1210/VCR cells are also resistant to CisPt. However, resistance to this substance could not be reversed by addition of the known P-gp inhibitor verapamil. CisPt induced more pronounced entry into apoptosis, as measured using the annexin V/propidium iodide kit, in sensitive L1210 cells than in resistant L1210/VCR cells. In addition, CisPt induced an increase in the proportion of L1210 cells that were in the g2 phase of the cell cycle when compared to L1210/VCR cells, as measured by staining with propidium iodide. Similarly, a higher release of cytochrome c from the mitochondria to the cytosol was induced by CisPt treatment in L1210 than in L1210/VCR cells.

While similar levels of Bax and Bcl-2 proteins were observed in sensitive and resistant cells, CisPt induced a more pronounced decrease of the Bcl-2 levels in L1210 cells than in L1210/VCR cells. Consistent with this observation, CisPt induced a larger decrease of the Bcl-2 content in the Bcl-2:Bax heterooligomer in L1210 cells than in L1210/VCR cells. Moreover, CisPt induced a similar apoptotic DNA fragmentation pattern in both resistant and sensitive cells.

All of the above observations indicated that L1210/VCR cells are also resistant to CisPt and that this resistance is related to the differences in the regulatory mechanisms responsible for CisPt-induced apoptosis in L1210/VCR cells without any contribution from the drug efflux activity of P-gp.
\end{abstract}

Key words: P-gp-mediated MDR - Cisplatin-induced apoptosis - Bcl-2 protein - Bax protein — L1210 - cytochrome c release

\footnotetext{
Correspondence to: Zdena Sulová, Institute of Molecular Physiology and Genetics, Slovak Academy of Sciences, Vlárska 5, 83334 Bratislava, Slovakia

E-mail: zdena.sulova@savba.sk
} 


\section{Introduction}

Multidrug resistance (MDR) represents a real obstacle in the effective chemotherapeutic treatment of neoplastic diseases (Pauwels et al. 2007). The massive overexpression of the plasma membrane protein P-glycoprotein (P-gp), an ABCB1 member of the $\mathrm{ABC}$ membrane transporter family, represents the most common feature that confers MDR (Zhou 2008). Cell selection with cytotoxic substances, that are P-gp substrates, leads to the creation of P-gp positive drug-resistant cell lines (Pop et al. 2008). The mouse leukemia cell line L1210/VCR represents an MDR cell sub-line that was selected for MDR from the parental L1210 cell line by the addition of vincristine (VCR) (Polekova et al. 1992). This cell line is characterized by the massive overexpression of P-gp (Fiala et al. 2003; Sulova et al. 2005), a mechanism that is responsible for its ability to confer drug resistance (Bohacova et al. 2000, 2006) in addition to its crossresistance to doxorubicin, cyclophosphamide, dexamethazone, mitomycin C and actinomycin D (Breier et al. 2000). Several alterations in the regulatory and metabolic pathways such as: i) changes in the expression and activity of regulatory kinases (Barancik et al. 2001, 2006; Kisucka et al. 2001), ii) changes in the expression of the nuclear receptors for retinoids (Sulova et al. 2008), iii) differences in the content and composition of saccharides that are particularly located on the cell surface (Sulova et al. 2009), and iv) changes in the expression of endoplasmic reticulum proteins involved in the regulation of calcium homeostasis (Seres et al. 2008) were found to be associated with P-gp overexpression in L1210/VCR cells. These alterations, coupled with the presence of a significant amount of P-gp in the plasma membrane, are responsible for the complex phenotype of P-gpmediated MDR (Breier et al. 2005).

The high expression levels of both P-gp and the proto-oncogene $\mathrm{Bcl}-2$ were reported to be associated with the in vitro resistance to chemotherapeutic agents and a poor clinical outcome in cases of acute myeloid leukemia (Campos et al. 1997) and in cases of adults who have acute lymphoblastic leukemia (Del Principe et al. 2003). Amount of Bcl-2 was shown to be reduced in tissues characterized by apoptotic cell death (Hockenbery et al. 1991). This protein hetero-oligomerizes in vivo with a conserved homolog, i.e. Bax, and this process is known to modulate apoptosis (Oltvai et al. 1993). Both these proteins are members of the $\mathrm{Bcl}-2$ family, and notably only Bcl-2 (like Bcl-XL, Mcl-1, Bcl-w and Bfl-1) was recognized as an anti-apoptotic protein, as opposed to Bax (like Bak, Bim, Bid, Bad, Bik, Puma, Noxa, Bmf, BNIP3, Bmf, Hrk, MULE), which is known to function as a pro-apoptotic protein (Brunelle and Letai 2009). The translocation of the Bax (or Bak) monomer from the cytosol to the mitochondria followed by the formation of $\mathrm{Bax}$ (or Bak) homo-oligomers represents a physiological death stimulus, which may be antagonized by the presence of the Bcl-2 protein (or other anti-apoptotic proteins) that prevents Bax homo-oligomerization (Brunelle and Letai 2009; Gross et al. 1998). Homo-oligomerization of the pro-apoptotic proteins participate in the formation of pores in the outer mitochondrial membrane through which pro-apoptotic molecules like cytochrome c escape the mitochondria and initiate apoptosis via the activation of caspases (Degli Esposti and Dive 2003; Brunelle and Letai 2009). The overexpression of anti-apoptotic proteins from the Bcl-2 family is commonly associated with an unfavorable pathogenesis in neoplastic diseases (Lessene et al. 2008).

We have previously described an increase in the Bcl-2 protein content and a decrease in the cleaved-activated caspase 3 content in L1210/VCR cells upon comparison with L1210 cells (Barancik et al. 2006). Thus, the drug resistance of L1210/VCR cells could include a less significant apoptotic response from chemotherapeutic agents due to an alteration in the apoptotic regulatory pathways that may be an sinergistic mechanism with the P-gp-mediated drug elimination from the cells. To prove this hypothesis, we need to characterize the differences in the mechanism of apoptosis entry between L1210 and L1210/VCR cells.

Apoptosis may be induced in neoplastic cell lines using a variety of anticancer drugs. Cisplatin (CisPt) was reported to induce apoptotic DNA fragmentation in human promyelocytic leukemia HL-60 cells and murine leukemia L1210 cells (Cipak et al. 2003). Drug resistance induced by CisPt was not found to be a consequence of the overexpression of either MDR1 or MDR3 gene products in ovarian carcinoma cell lines (Ren et al. 2007). While the adaptation of the human ovarian cancer cell line SKOV3 to CisPt, which yields a CisPt resistant sub-line (SKOV3/CIS), was accompanied by the overexpression of P-gp, P-gp alone was not found to be responsible for the resistance to CisPt conferred by this sub-line (Yang and Page 1995). However, SKOV3/CIS was cross-resistant to P-gp substrates such as doxorubicin, taxol and actinomycin $\mathrm{D}$, and resistance to these latter three substances was sensitive to verapamil, which is a well-known $\mathrm{P}$-gp inhibitor, in contrast to CisPt resistance, which was unaffected by treatment with verapamil. CisPt resistance was found to be associated with an upregulation of $\mathrm{Bcl}-2$ and the subsequent inhibition of Bax translocation from the cytosol to the mitochondria (Cho et al. 2006).

The aim of the current paper is to answer the question of whether or not any differences exist in CisPt-induced apoptosis between a P-gp negative L1210 cell line and a P-gp positive L1210/VCR cell line.

\section{Materials and Methods}

\section{Cell cultivation conditions}

The following cell variants were used: sensitive L1210 cells (S) and a drug-resistant L1210/VCR cell line, which was 
cultivated prior to experiments in the absence of VCR (R) and in the presence of $1.08 \mu \mathrm{mol} / \mathrm{l} \operatorname{VCR}(\mathrm{V})$. VCR was supplied by Gedeon Richter Co. (Hungary). The resistant cell sub-line L1210/VCR was obtained by selection with increasing concentrations of VCR (Polekova et al. 1992). This cell sub-line represents the MDR cell model that is characterized by a significant expression of P-gp (Fiala et al. 2003; Sulova et al. 2009), in which other markers of MDR, such as glutathione S-transferase, MRP1 (multidrug resistance protein 1) and BCRP (breast cancer resistance protein) were not found to be changed (Bohacova et al. 2000, 2006). The cells (S, R and V) were cultivated in RPMI 1640 medium with L-glutamine $(1 \mathrm{mg} / \mathrm{ml}), 4 \%$ fetal bovine serum and $1 \mu \mathrm{g} / \mathrm{ml}$ gentamycin (all purchased from Gibco, USA) in a humidified atmosphere with $5 \% \mathrm{CO}_{2}$ in air at $37^{\circ} \mathrm{C}$ for either 24 or $48 \mathrm{~h}$.

\section{Effect of CisPt on the viability of $S, R$ and $V$ cells}

Cells $\left(5 \times 10^{4}\right.$ cells per each well $)$ were cultivated in the absence or presence of various concentrations of CisPt in combination with verapamil $\left(10 \mu \mathrm{mol} / \mathrm{l}^{\star}\right)$ in 96 -well culture plates. Verapamil, CisPt and vincristine were added directly to the cultivation medium. For $\mathrm{V}$ cells, vincristine was present during the cultivation of the cells with CisPt. After $48 \mathrm{~h}$, the cell viability was assayed using a MTT test (Gerlier and Thomasset 1986) that was performed by the addition of MMT (3-(4,5-dimethyldiazol-2-yl)-2,5 diphenyl tetrazolium bromide) at a final concentration of $0.5 \mathrm{mg} / \mathrm{ml}$ to each well followed by a $2 \mathrm{~h}$ incubation period. Then the plates were centrifuged for $15 \mathrm{~min}$ (2500 rpm), after which the cell sediment was extracted using dimethyl sulfoxide. The absorbance at $540 \mathrm{~nm}$ was then measured.

The concentration dependence of CisPt-induced cell death was fit using Eq. (1) (Kupsakova et al. 2004):

$$
\mathrm{N}=100 \% \times \exp \left[\ln (0.5) \times\left(\mathrm{c} / \mathrm{IC}_{50}\right)^{\mathrm{n}}\right]
$$

where $\mathrm{N}$ represents the proportion of viable cells after cultivation in the presence of CisPt at concentration $\mathrm{c}$. The $\mathrm{IC}_{50}$ is the median lethal concentration, and $\mathrm{n}$ is the order exponent.

The experimental data were fit by nonlinear regression using SigmaPlot Graphing Software (version 2.01). The significance differences were analyzed using the unpaired Student's $t$-test.

\footnotetext{
${ }^{*}$ Verapamil at the applied concentration was found to completely antagonize P-gp activity in R cells measured with Calcein/AM and Fluo-3/AM as fluorescent substrates of P-gp.
}

Detection of apoptosis and necrosis induced in $S, R$ and $V$ cells by CisPt

Cells $\left(1 \times 10^{6}\right.$ cells per $\left.\mathrm{ml}\right)$ were incubated for 4,12 or $24 \mathrm{~h}$ in the absence or presence of various CisPt concentrations under standard cultivation conditions. After these incubation periods, the proportions of apoptotic and necrotic cells were detected using an annexin V/propidium iodide kit (Calbiochem, USA) according to procedure described by the manufacturer. Briefly, the cells were washed twice with PBS and gently resuspended in binding buffer containing $0.5 \mu \mathrm{g} / \mathrm{ml}$ annexin $\mathrm{V}$ labeled with fluorescein isothiocyanate (FITC). The mixtures were incubated for $15 \mathrm{~min}$ at room temperature in the dark and then centrifuged (2500 rpm, $15 \mathrm{~min})$. The resulting sediments were resuspended in binding buffer, and propidium iodide (final concentration $0.6 \mu \mathrm{g} / \mathrm{ml}$ ) was added to each sample, after which the samples were analyzed by flow cytometry using a Coulter Altra flow cytometer (Beckman coulter USA).

Effect of CisPt on the proportion of $S$ and $R$ cells in different phases of the cell cycle

Cells $\left(1 \times 10^{6}\right.$ cells per $\left.\mathrm{ml}\right)$ were incubated for $12 \mathrm{~h}$ in the absence or presence of CisPt (10 and $25 \mathrm{mg} / \mathrm{l}$ ) under standard cultivation conditions and were then washed with PBS and resuspended in $0.05 \%$ Triton X-100 dissolved in PBS containing $0.1 \mathrm{mg} / \mathrm{ml}$ RNase A and incubated for $20 \mathrm{~min}$ at $37^{\circ} \mathrm{C}$. The final mixtures were cooled on ice for $10 \mathrm{~min}$, and propidium iodide $(40 \mu \mathrm{g} / \mathrm{ml})$ was added to the samples, which were then incubated on ice another $30 \mathrm{~min}$. Finally, the fluorescence of propidium iodide was monitored using a Coulter Altra flow cytometer for each sample.

\section{Detection of the effect of CisPt on the Bcl-2, Bax and P-gp} content in $S$ and $R$ cells using Western blot assays

Cells ( $\mathrm{S}$ and $\mathrm{R}$ ) were cultivated in standard medium for $48 \mathrm{~h}$ in the absence or presence of CisPt $(1 \mathrm{mg} / \mathrm{l})$ and verapamil $(10 \mu \mathrm{mol} / \mathrm{l})$. After incubation, the cells were harvested, and the whole cell lysates were prepared by homogenization in RIPA buffer (Pierce Biotechnology, USA) according to the manufacturer's instructions. Briefly, the cells were washed twice in PBS and centrifuged (2800 $\mathrm{rpm}, 5 \mathrm{~min}$ ), and the pellets were extracted using RIPA buffer for $15 \mathrm{~min}$ under shaking. The resulting sample was centrifuged (11 $200 \mathrm{rpm}, 15 \mathrm{~min}$ ), and the supernatants were stored for further analysis. In addition, the protein concentration was determined using the Lowry assay. The protein content in samples was separated using SDS-PAGE in $12 \%$ SDS-polyacrylamide gel (Laemmli 1970) and then 
transferred to a nitrocellulose membrane (Amersham, USA) by electro-blotting (Towbin et al. 1979). Rabbit antiBcl-2 (N-19) and anti-Bax (N-20) polyclonal antibodies (Santa Cruz Biotechnology, USA) were used as primary antibodies, while goat anti-rabbit IgG conjugated with horseradish peroxidase (Santa Cruz Biotechnology, USA) served as a secondary antibody that was used for protein detection on the blot. Either a monoclonal anti-P-gp antibody (c219, Calbiochem, USA) or an anti-GAPDH antibody (Santa Cruz Biotechnology, USA) in addition to an anti-mouse antibody conjugated with horseradish peroxidase (Calbiochem, USA) was used for P-gp and GAPDH detection, the latter of which served as an internal detection standard. The protein signals were visualized with an ECL detection system (Amersham, USA) using a Kodak (USA) scanning system CF 440.

\section{Detection of the Bax:Bcl-2 complexes by immuno-precipitation}

Cells $\left(1 \times 10^{8}\right)$ were cultivated as described in the previous chapter and then were lysed in $50 \mathrm{mmol} / \mathrm{l}$ Tris- $\mathrm{HCl}$ (pH 7.4) containing $150 \mathrm{mmol} / \mathrm{l} \mathrm{NaCl}$ and $1 \%$ Nonidet P40 (Roche, Germany) for $15 \mathrm{~min}$ at $1^{\circ} \mathrm{C}$ under intensive shaking. Proteins were adjusted to a final concentration of $400 \mu \mathrm{g} / \mathrm{ml}$ by the addition of $50 \mathrm{mmol} / \mathrm{l}$ Tris- $\mathrm{HCl}(\mathrm{pH}$ 7.4), after which either the anti-Bax or anti-Bcl-2 antibody (described in the previous chapter) was added. After $2 \mathrm{~h}$ of incubation at $4^{\circ} \mathrm{C}, 20 \mu \mathrm{l}$ of protein A/G PLUS-agarose (Santa Cruz Biotechnology, USA) was added, and the mixture was shaken overnight at $4^{\circ} \mathrm{C}$. Afterwards, the precipitates were centrifuged $\left(10000 \mathrm{rpm}, 10 \mathrm{~min}, 4^{\circ} \mathrm{C}\right)$ and washed twice in $50 \mathrm{mmol} / \mathrm{l}$ Tris- $\mathrm{HCl}(\mathrm{pH} \mathrm{7.4})$. The presence of $\mathrm{Bax}$ or $\mathrm{Bcl}-2$ in the immuno-precipitated samples was estimated using the Western blot procedure as described above.

\section{Detection of $\mathrm{Bcl}-2$ protein and cytochrome c by immuno- fluorescence}

Cells $\left(1 \times 10^{6}\right)$ were incubated for $24 \mathrm{~h}$ under standard cultivation conditions in either the absence or presence of CisPt $(10 \mu \mathrm{g} / \mathrm{ml})$. Afterward, the cells were washed and resuspended in PBS and were transferred onto poly-L-lysine cover glasses (Menzel Glaser, Germany). The bound cells were washed twice in PBS and then were fixed in methanol at $-20^{\circ} \mathrm{C}$ for $20 \mathrm{~min}$. After fixation, specimens were washed in PBS and then blocked by incubation with $1 \%$ BSA in PBS for $1 \mathrm{~h}$ at $37^{\circ} \mathrm{C}$. Subsequently, the specimens were incubated with the anti-Bcl-2 antibody (described in the previous chapters) or with the anti-cytochrome $\mathrm{c}$ antibody (Santa Cruz, USA) for $1 \mathrm{~h}$ at $37^{\circ} \mathrm{C}$ in PBS containing $1 \% \mathrm{BSA}$ and then were washed twice in PBS containing $1 \%$ BSA. Finally, specimens were also incubated with goat anti-rabbit IgG conjugated with FITC (Calbiochem, USA) in $1 \% \mathrm{BSA}$ and PBS for $1 \mathrm{~h}$ at $37^{\circ} \mathrm{C}$ and then washed twice in PBS containing 1\% BSA. The specimens labeled by immuno-fluorescence were additionally labeled using a solution of $10 \mathrm{mg} / \mathrm{l}$ 4'-6-diamidino-2-phenylindole (DAPI; Sigma, USA) in PBS to visualize the nuclei (Krishan and Dandekar 2005). Finally, the cover-slips were mounted onto slides with a mounting medium ( $80 \%$ glycerol) and analyzed using a confocal laser-scanning microscope LSM 510 META Carl Zeiss.

\section{Estimation of CisPt-induced apoptotic DNA fragmentation} in $S, R$ and $V$ cells

Cells S, R and V $\left(1 \times 10^{6}\right)$ were incubated in the absence or presence of CisPt $(10 \mathrm{mg} / \mathrm{l})$ for $24 \mathrm{~h}$ under standard cultivation conditions, washed in PBS and then were used for the estimation of DNA fragmentation upon comparison to an Apoptotic DNA Ladder Kit (Roche, Germany) according to the procedure described by the manufacturer. Briefly, the cells were centrifuged (5 min at $2800 \mathrm{rpm}$ ) and resuspended in $200 \mu \mathrm{l}$ of PBS and 200 $\mu \mathrm{l}$ of binding lysis buffer and were then incubated for 10 min. Subsequently, $100 \mu \mathrm{l}$ of isopropanol was added to each sample, and the resulting mixtures were rigorously shaken. The samples were then transferred to the filter tube and centrifuged ( $8000 \mathrm{rpm}, 1 \mathrm{~min})$. These samples were subsequently washed twice in washing buffer, after which the DNA was extracted from the filter tube using pre-warmed $\left(70^{\circ} \mathrm{C}\right)$ elution buffer and centrifuged for $1 \mathrm{~min}$ at $8000 \mathrm{rpm}$. The concentration of DNA in these samples was estimated using photometry, and $30 \mu \mathrm{g}$ of DNA was mixed with a MassRuler Loading dye solution (Fermentas, Latvia) in each sample. Subsequently, samples were loaded onto a $1.5 \%$ agarose gel containing 0.5 $\mu \mathrm{g} / \mathrm{ml}$ ethidium bromide $(\mathrm{EtBr})$ immersed in a TAE (Trisacetate-EDTA) buffer. Electrophoresis was performed at $75 \mathrm{~V}$, the DNA was stained with EtBr in-gel, and the DNA was detected using Typhoon 9400 (Amersham, USA).

\section{Results and Discussion}

\section{Cytotoxic effect of CisPt on $S, R$ and $V$ cells}

CisPt induced a strong cell death effect that was more pronounced in S cells than in R and V cells (Fig. 1A). This indicated that $\mathrm{R}$ and $\mathrm{V}$ cells are less sensitive to $\mathrm{Cis} \mathrm{Pt}$ than $\mathrm{S}$ cells. On the other hand, no significant differences were observed for the CisPt cell death effect between $\mathrm{R}$ and $\mathrm{V}$ cells. Thus, the presence of VCR during the cultivation of $\mathrm{V}$ cells in medium containing different concentrations of CisPt did not induce any additional increase in cell damage 
A

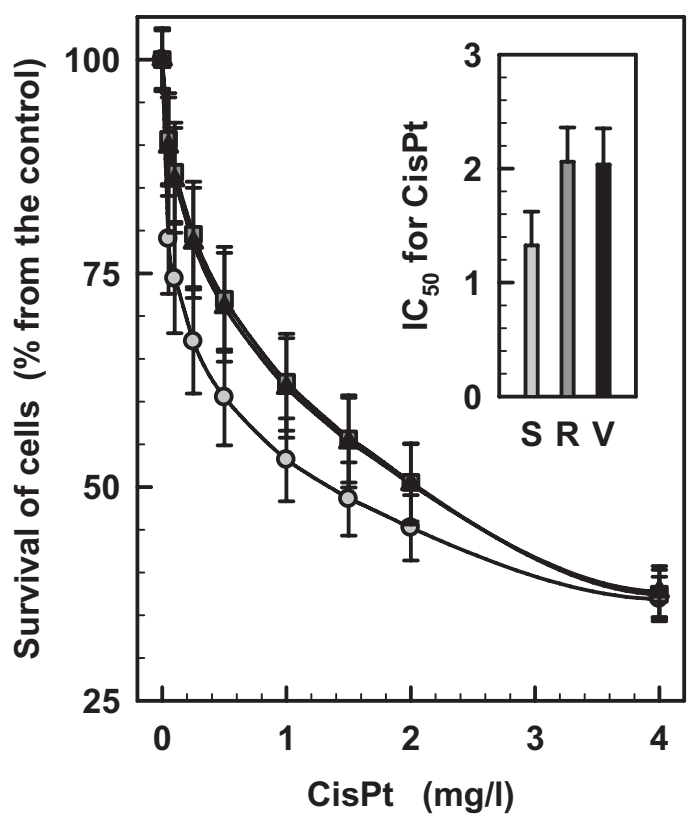

B

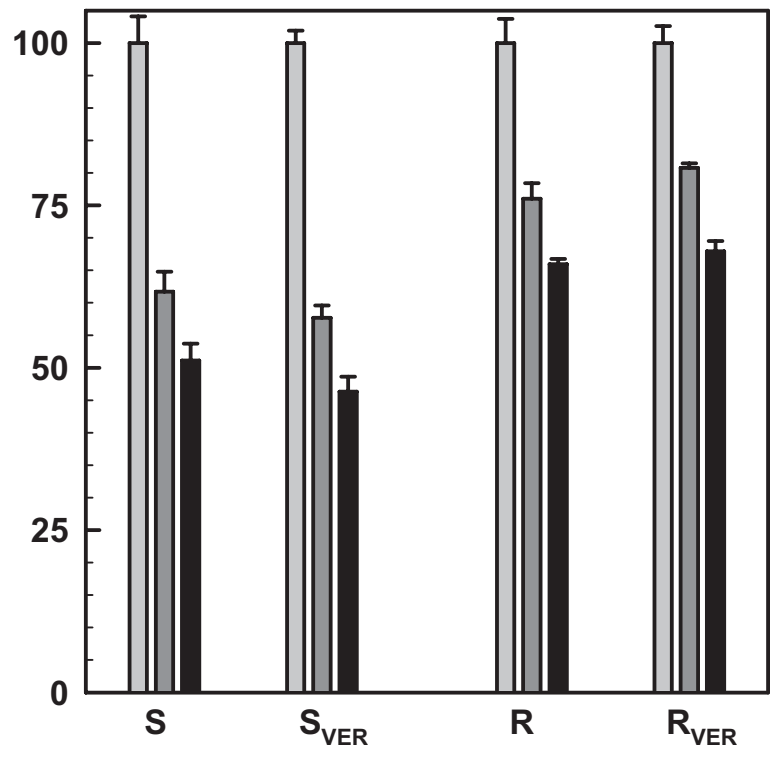

CisPt in mg/l: $\square 0.0 ; \square 0.5 ; \square 1.0$

Figure 1. The cell damage effect of CisPt on S, R and V cells. Panel A: The concentration dependence of the CisPt effect. Symbols: Circles - S cells; squares - R cells; triangles - V cells. The cells were cultivated for two days in the presence of CisPt at their specified concentrations. The experimental data are expressed as the mean \pm SD for six independent experiments and were fit according to Eq. (1) using nonlinear regression. Inserted panel: The values of CisPt $\mathrm{IC}_{50}$ for the CisPt effect on $\mathrm{S}, \mathrm{R}$ and $\mathrm{V}$ cells. The data were represented as the computed value $\pm \mathrm{SD}$. The $\mathrm{IC}_{50}$ value for $\mathrm{S}$ cells differed significantly from the $\mathrm{IC}_{50}$ values for both $\mathrm{R}$ and $\mathrm{V}$ cells at the level $p<0.01$. Panel B: The effect of verapamil (VER) on the CisPt-induced cell damage of S and R. VER $(10 \mu \mathrm{mol} / \mathrm{l})$ was added together with CisPt. These data are expressed as the mean \pm SD of six independent experiments. The values obtained in the presence of VER and CisPt did not differ significantly from the data obtained in the presence of CisPt alone.

as CisPt alone was induced in $\mathrm{R}$ cells. This indicated that a reduced sensitivity of $\mathrm{R}$ and $\mathrm{V}$ cells to CisPt was induced by a mechanism distinct from P-gp-mediated drug efflux. To prove this hypothesis, we measured the effect of verapamil (a well-known inhibitor of P-gp) at a concentration at which verapamil completely antagonizes the transport activity of P-gp in L1210/VCR cells (Orlicky et al. 2004). Interestingly, verapamil was unable to induce any potentiation of the cell damage effect induced by CisPt in both $S$ and R cells (Fig. 1B). On the contrary, verapamil and other known P-gp antagonists were shown to significantly reduce the $\mathrm{P}$-gp-mediated vincristine resistance of $\mathrm{R}$ cells (Poleková et al. 1992; Barancik et al. 1994). Moreover, verapamil fully depressed P-gp-mediated protection of $\mathrm{R}$ cells against intracellular retention of Fluo-3 and calcein in experiments where Fluo-3/AM and Calcein/AM were applied as P-gp substrates (Orlicky et al. 2004; Bohacova et al. 2006). This clearly indicated that the significant amount of P-gp present in R and V cells (Fiala et al. 2003; Sulova et al. 2005, 2009) in addition to its transport activity is not responsible for the lower sensitivity of these cells to CisPt as compared to $\mathrm{S}$ cells. Therefore, the lower sensitivity of $\mathrm{R}$ and $\mathrm{V}$ cells to CisPt must be due to a mechanism that is fundamentally distinct from P-gp-mediated drug efflux activity. This is in agreement with the fact that P-gp was not involved in resistance to CisPt (Ren et al. 2007). However, cells treated with CisPt using different protocols may express a higher amount of P-gp as compared to their non-treated counterpart cells (Takara et al. 2003; Yan et al. 2007). In addition, the overexpression of P-gp was accompanied with a lower sensitivity to CisPt in the HOB $1 /$ VCR cell variant that was prepared in a similar fashion as L1210/VCR cells by selection of parental cells using vincristine (Chao 1996; Tsai et al. 2007). It should be stressed that resistance to P-gp transportable drugs via the overexpression of $\mathrm{P}$-gp and the resistance to $\mathrm{Cis} \mathrm{Pt}$ by a mechanism distinct from P-gp-mediated drug efflux activity may occur together independently if resistant cells were selected using a P-gp substrate such as vinca alkaloids or with CisPt. 

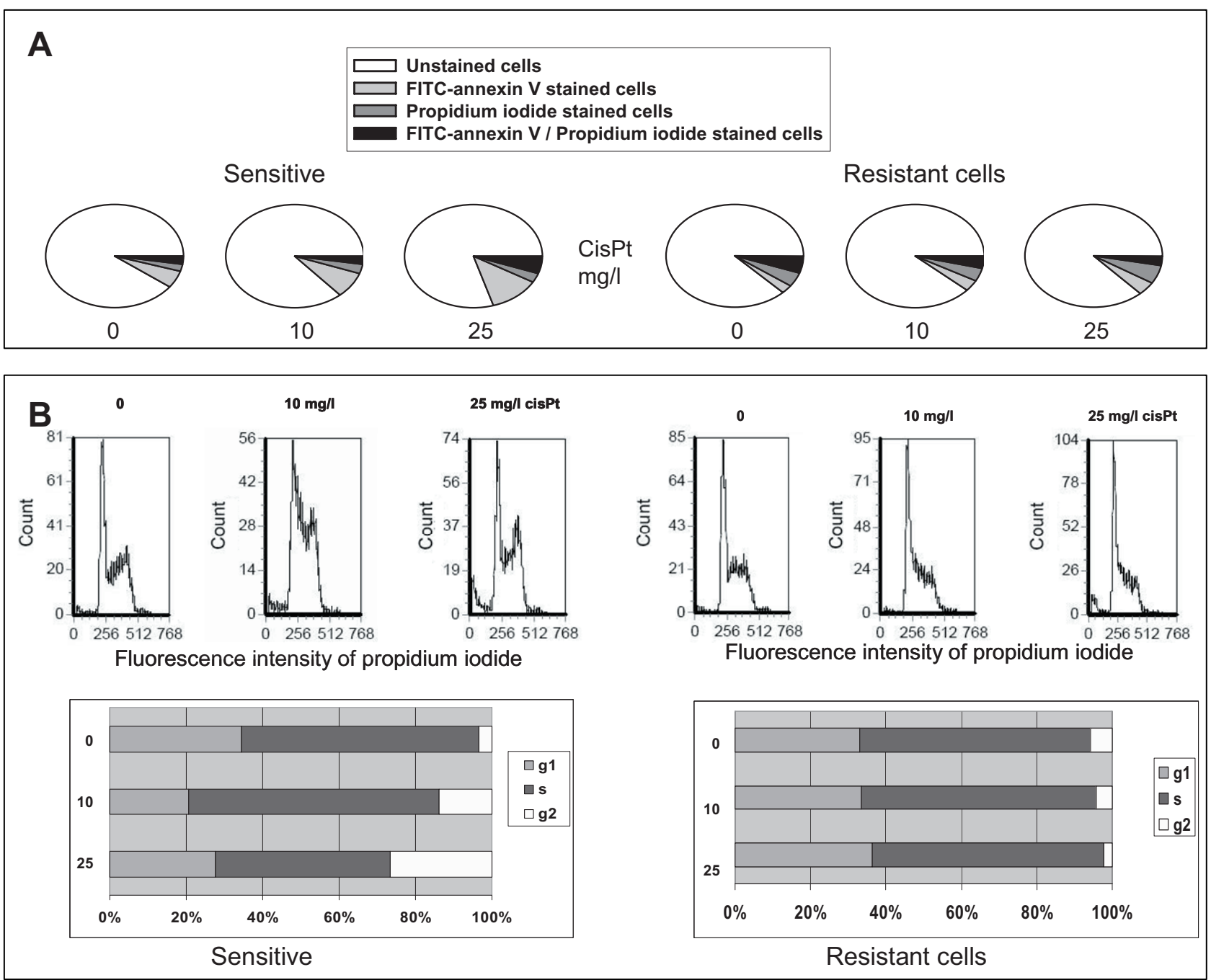

Figure 2. The characterization of the CisPt-induced cell death effect on $\mathrm{S}$ and $\mathrm{R}$ cells after a $12 \mathrm{~h}$ incubation with the specified concentration of CisPt. These data represent typical results from three independent experiments. Panel A: The determination of the proportion of cells entering apoptosis and necrosis using an annexin V/propidium iodide kit. Panel B: The estimation of the CisPt effect on the proportion of $\mathrm{S}$ and $\mathrm{R}$ cells in $g 1, s$ and $g 2$ phase of the cell cycle using the propidium iodide staining method.

\section{CisPt induced apoptosis and necrosis in $S, R$ and $V$ cells}

The sorting of apoptotic and necrotic cells after staining with FITC-labeled annexin $\mathrm{V}$ and propidium iodide was applied to cells pre-incubated with $\operatorname{CisPt}(0,1,10,25 \mathrm{mg} / \mathrm{l})$ for 12 and $24 \mathrm{~h}$. These two time intervals were chosen because when cells were pre-incubated for $4 \mathrm{~h}$, any differences between $\mathrm{S}, \mathrm{R}$ and $\mathrm{V}$ cells pre-incubated in the presence or absence of CisPt were not observed, and the pre-incubation of cells with CisPt (namely at higher concentrations) for $48 \mathrm{~h}$ induced massive cell damage where a majority of the counted cells were labeled by both annexin V linked with FITC and propidium iodide. The pre-incubation of S cells with CisPt for $12 \mathrm{~h}$ induced a concentration-dependent increase in the number of cells stained by FITC-labeled annexin $\mathrm{V}$, i.e. cells that enter apoptosis (Fig. 2A). The addition of CisPt at its highest concentration $(25 \mathrm{mg} / \mathrm{l})$ also resulted in an increase in the proportion of cells that were stained by both FITC-labeled annexin $\mathrm{V}$ and propidium iodide. The effect of CisPt on R cells (Fig. 2A) was less pronounced when compared to its effect on $\mathrm{S}$ cells. No significant differences were observed between $\mathrm{R}$ and $\mathrm{V}$ cells in this regard (not shown).

Analysis of the cell cycle revealed that the proportion of S, R (Fig. 2B) and also V cells (not shown) in $g 1, s$ or $g 2$ phase did not differ. However, when CisPt was present at 


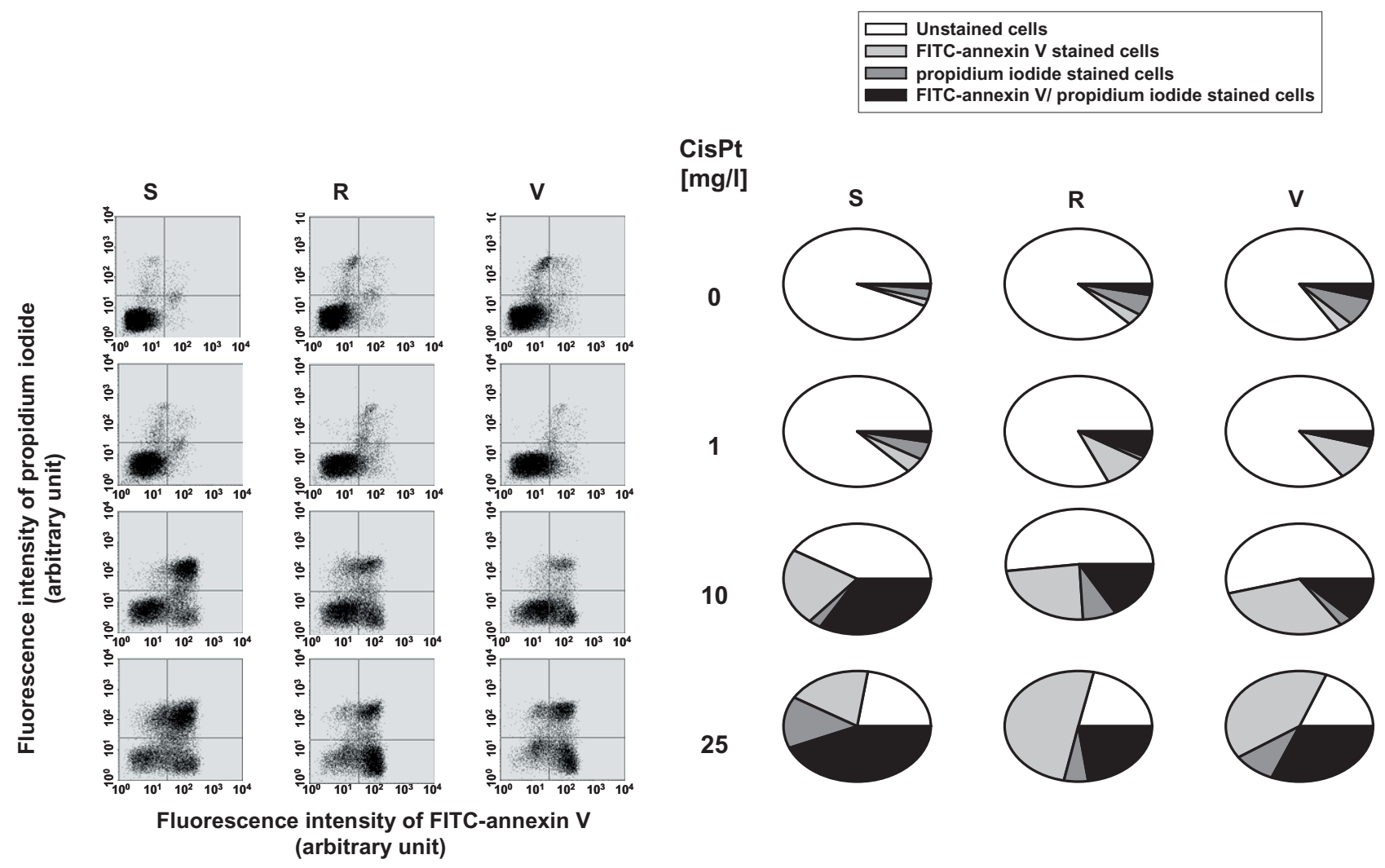

Figure 3. The determination of CisPt-induced S, R and V cells entering apoptosis or necrosis using the annexin V/propidium iodide kit. These data represent typical results from three independent experiments. All details about experimental procedures are described in chapter Materials and Methods.

concentrations of 10 and $25 \mathrm{mg} / \mathrm{l}$ for a period of $12 \mathrm{~h}$, the proportion of $\mathrm{S}$ cells in $g 2$ phase increased in a manner that was associated with a reduction in the number of cells in the $s$ and $g 1$ phases of the cell cycle (Fig. 2B). The progression of $g 2$ phase in L1210 cells after CisPt treatment has been described previously (Sorenson et al. 1990), and this was reported to be related to apoptosis. Under the same conditions, the proportions of $\mathrm{R}$ (Fig. 2B) and $\mathrm{V}$ cells (not shown) in each individual cell cycle phase did not change. The absence of CisPt-induced effect on the amount of $\mathrm{R}$ and $\mathrm{V}$ cells in $g 2$ phase may be related to an overall decrease in the sensitivity of these cells to this drug. Interestingly, the application of the alltrans retinoic acid and FK228 substance (novel histone deacetylase inhibitor depsipeptide) induced P-gp expression and the subsequent arrest of NB4 APL cells in the $g 1$ phase of the cell cycle and also reduced the sensitivity to DOX, which is known to induce apoptosis in the $g 2$ phase (Tabe et al. 2006).

The majority of S cells were dead as evidenced by the observation that they bound both FITC-labeled annexin $\mathrm{V}$ and propidium iodide when these cells were pre-incubated with CisPt (at $25 \mathrm{mg} / \mathrm{l}$, Fig. 3) for $24 \mathrm{~h}$. In contrast, after pre-incubation of the $\mathrm{R}$ and $\mathrm{V}$ cells under the same conditions, while a majority of cells bound the FITC-labeled annexin V, and thus entered apoptosis (Fig. 3), their cell membrane was still not permeable to propidium iodide. Pre-incubation of S, $\mathrm{R}$ and $\mathrm{V}$ cells with CisPt at a concentration of $10 \mathrm{mg} / \mathrm{l}$ for $24 \mathrm{~h}$ induced similar yet less pronounced effects. The application of $\mathrm{CisPt}$ in this experiment at a concentration of $1 \mathrm{mg} / \mathrm{l}$ induced modest effects on $\mathrm{S}, \mathrm{R}$ and $\mathrm{V}$ cells that were statistically insignificant (Fig. 3).

CisPt induced the release of cytochrome $c$ to the cytoplasm in $S, R$ and $V$ cells

The release of cytochrome $\mathrm{c}$ from the mitochondria to the cytoplasm represents phenomena that are directly related to apoptosis (Degli Esposti and Dive 2003; Brunelle and Letai 2009). The escape of cytochrome $c$ from the mitochondria can be monitored by immuno-cytochemistry using permeabilized cells and antibodies against cytochrome c (Dave et al. 2008). Cytochrome $c$ is localized in the small intracellular 
Control
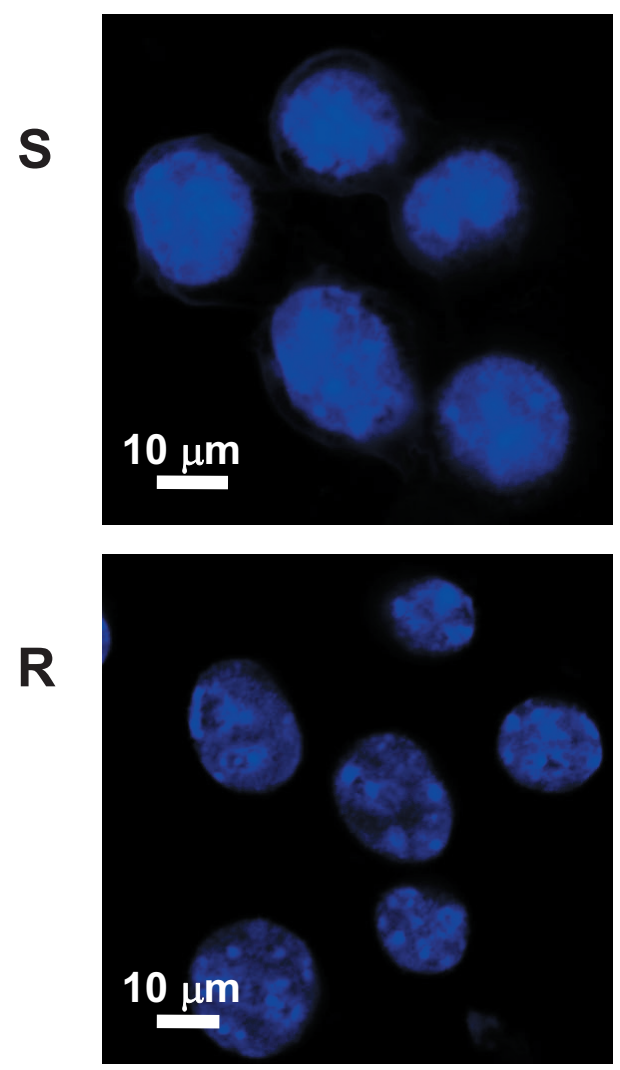

$0 \mathrm{mg} / \mathrm{l} \mathrm{CisPt}$
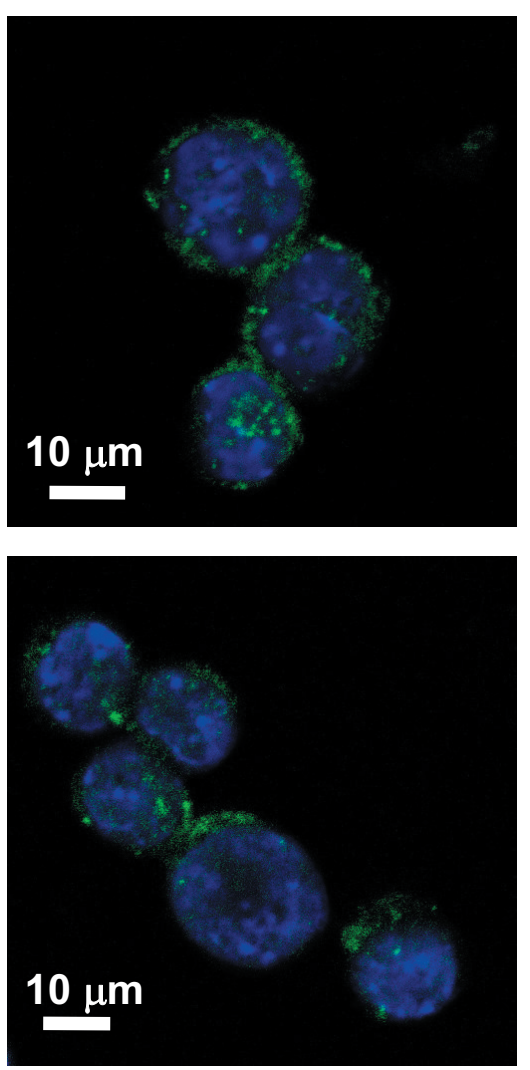

$10 \mathrm{mg} / \mathrm{l} \mathrm{CisPt}$
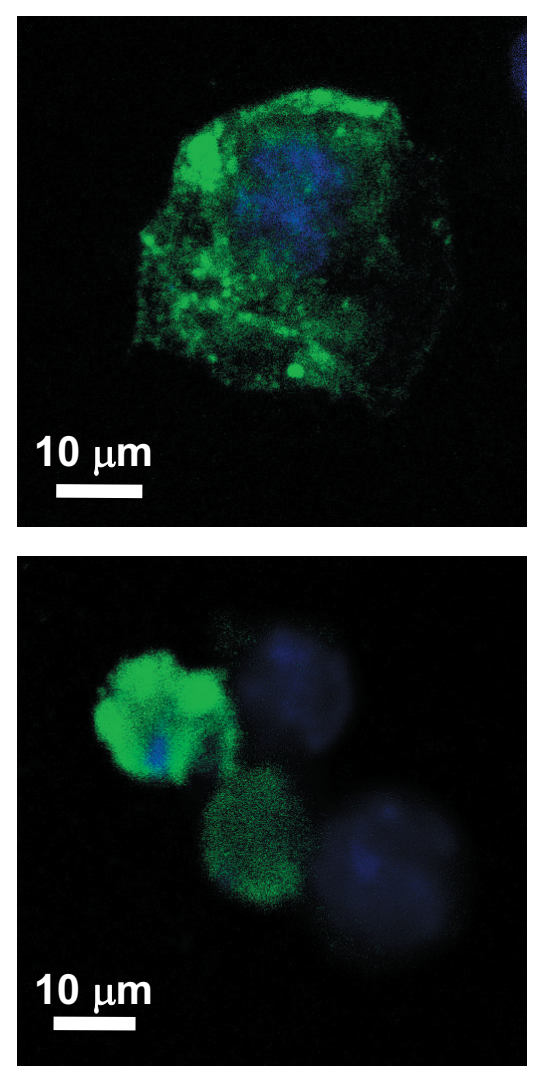

Figure 4. The visualization of CisPt-induced cytochrome c release from the mitochondria to the cytosol. S and R cells were pre-incubated for $24 \mathrm{~h}$ with CisPt prior to immuno-staining. The cells were stained with the FITC-labeled anti-cytochrome c antibody and with DAPI. In control experiments, FITC-labeled anti-cytochrome c was not applied. All details about experimental procedures are described in chapter Materials and Methods.

particles surrounding the nuclei that are stained by DAPI in the $\mathrm{S}$ and $\mathrm{R}$ cells pre-incubated in the absence of CisPt (Fig. 4). This staining pattern is consistent with mitochondrial localization of cytochrome $c$. The pre-incubation of cells with CisPt $(10 \mathrm{mg} / \mathrm{ml})$ for $24 \mathrm{~h}$ induced a significant release of cytochrome $\mathrm{c}$ to the cytoplasm in S cells (Fig. 4). In contrast, under the same conditions, the release of cytochrome $\mathrm{c}$ in $\mathrm{R}$ cells is much less pronounced. The similar patern of cytochrome $\mathrm{c}$ release was published previously (Laane et al. 2007) for the B-lineage of the acute lymphoblastic leukemia RS4 cells, in which apoptosis was induced by the addition of dexamethaone.

Effect of CisPt on the content of Bcl-2, Bax and the Bcl-2: Bax complex in $S$ and $R$ cells

$\mathrm{S}$ cells did not contain any amount of P-gp as indicated by Western blot analysis using the c219 antibody (Fig. 5A). In contrast, $\mathrm{R}$ cells were characterized by a significant amount of P-gp that could be decreased by cultivation of the cells in the presence of verapamil $(10 \mathrm{mg} / \mathrm{l})$ but not in the presence of CisPt $(1 \mathrm{mg} / \mathrm{l})$. Previously, we showed that verapamil induced a decrease in the expression of P-gp in R cells (Sulova et al. 2009). Consistently verapamil induced downregulation of P-gp expression in LLC-GA5-COL150 cell monolayers (Takara et al. 2002).

$\mathrm{S}$ and $\mathrm{R}$ cells did not differ in the expression levels of Bcl-2 or the Bax protein (Fig. 5B). The cultivation of $S$ cells in the presence of CisPt $(1 \mathrm{mg} / \mathrm{l})$ induced a strong decrease in the Bcl-2 content (Fig. 5C). However, the decrease in the $\mathrm{Bcl}-2$ content induced by cultivation of cells in the presence of CisPt was less pronounced in $\mathrm{R}$ cells. The presence of CisPt during cultivation of $\mathrm{S}$ and $\mathrm{R}$ cells did not induce changes in the levels of the Bax protein comparable to the changes in the $\mathrm{Bcl}-2$ protein. In contrast, the cultivation of $\mathrm{S}$ and $\mathrm{R}$ cells in the presence of verapamil did not induce detectable changes in the levels of the $\mathrm{Bcl}-2$ protein. Similar changes in the content of the $\mathrm{Bcl}-2$ protein were observed 

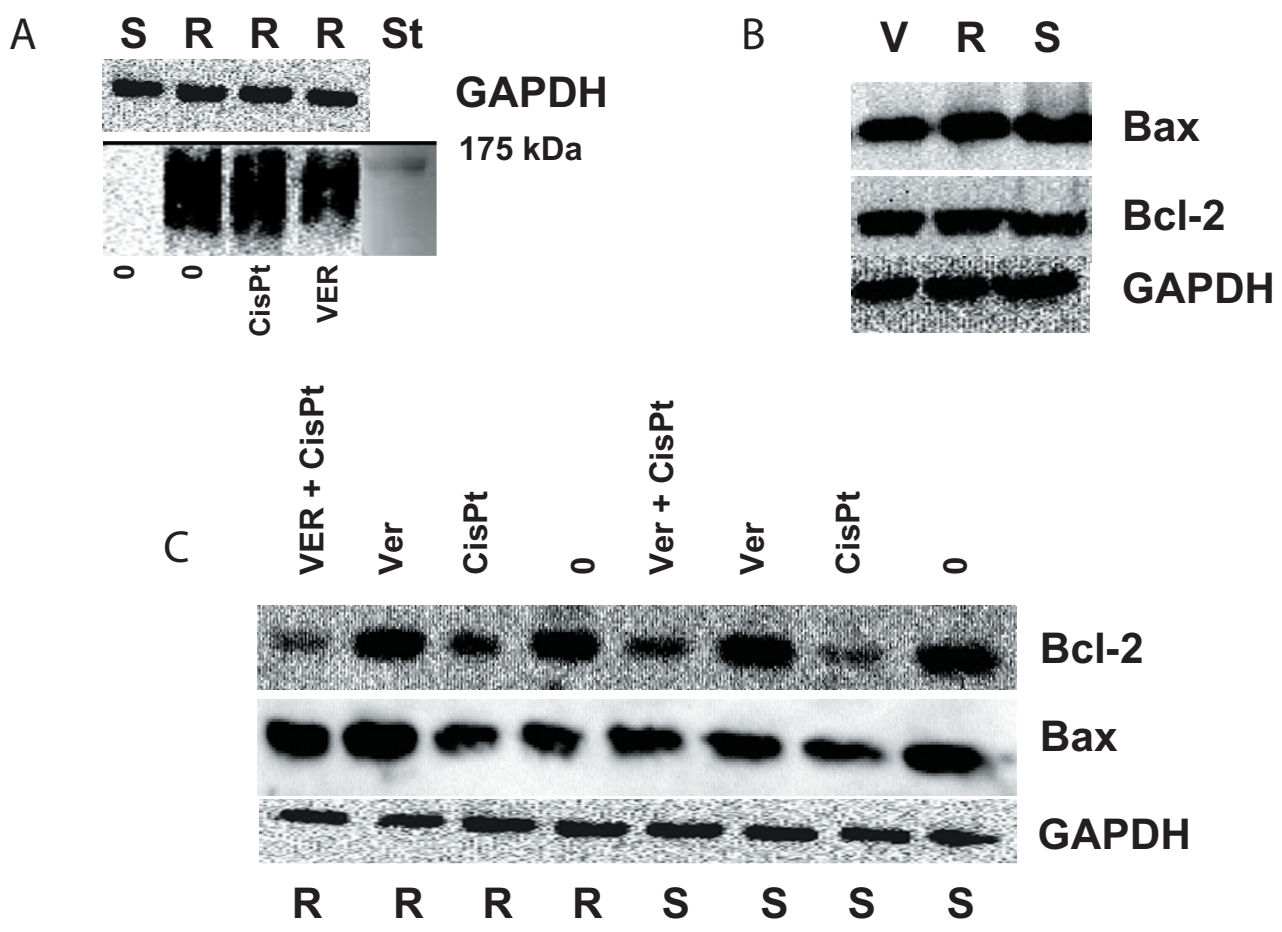

Figure 5. The effects of CisPt and VER on the protein levels of P-gp, Bcl-2 and Bax in S, R and V cells established using Western blot assays. Panel A: the effect of CisPt and VER on the level of P-gp in S and R cells. St, standard. Panel B: the levels of Bax and Bcl-2 in S, R and V cells. Panel C: the effect of VER and CisPt on the levels of Bax and Bcl-2 in S and R cells. GAPDH was used as internal standard. St was used as marker of molecular weight. These data represented typical results from three independent experiments.

in $\mathrm{S}$ and $\mathrm{R}$ cells after cultivation in the presence of both CisPt and verapamil as detected in the presence of CisPt alone during cultivation. This provides strong evidence that the P-gp efflux activity in R cells is not responsible for the less pronounced decrease in the expression of the $\mathrm{Bcl}-2$ protein induced by $\mathrm{Cis} \mathrm{Pt}$ as observed in $\mathrm{S}$ cells. The lower amount of the Bcl-2 protein observed in S cells after CisPt treatment during cell cultivation could not effectively prevent the pro-apoptotic Bax protein homo-oligomerization that is responsible for the induction of apoptosis. A less pronounced decrease of $\mathrm{Bcl}-2$ expression in $\mathrm{R}$ cells after cultivation in the presence of CisPt indicated a less considerable apoptotic stimulus in $\mathrm{R}$ cells after induction with CisPt in these cells and is related to the resistance of $\mathrm{R}$ cells to CisPt.

Immuno-cytochemical staining of $\mathrm{Bcl}-2$ using the anti$\mathrm{Bcl}-2$ antibody also revealed a less pronounced decrease of the Bcl-2 content in R cells as compared to S cells after cultivation of these cells in the presence of CisPt (Fig. 6). While Bcl-2 is localized in small intracellular particles located proportionally around the nuclear envelope in $\mathrm{R}$ cells, these particles were present in large clusters in $S$ cells near the parts of nuclei, which other parts were without staining (Fig. 6). Both of these types of Bcl-2 localization patterns were shown previously in a study of $\mathrm{Bcl}-2$ protein expression in chronic lymphocytic leukemia (Marschitz et al. 2000).

We needed to establish whether or not the cultivation of $\mathrm{S}$ and $\mathrm{R}$ cells in the presence of $\mathrm{CisPt}$ induced changes in the proportion of $\mathrm{Bcl}-2$ and $\mathrm{Bax}$ found in the $\mathrm{Bcl}-2$ : $\mathrm{Bax}$ complex. For this reason we used immuno-precipitation assays with $\mathrm{Bcl}-2$ and the Bax antibody. The cultivation of $\mathrm{S}$ cells in the presence of CisPt induced a decrease of the Bcl-2 protein in the immuno-precipitate obtained using the anti-Bax antibody (Fig. 7). This decrease is less pronounced in $\mathrm{R}$ cells after cultivation in the presence of CisPt. In specimens obtained by immuno-precipitation using the anti-Bcl-2 antibody, no considerable changes in Bax content after cultivation of either S or R cells were observed (Fig. 7). This indicated that the $\mathrm{Bcl}-2$ but not the Bax content was a limiting factor in the formation of the Bcl-2:Bax complex after the cultivation of $S$ and $\mathrm{R}$ cells in the presence of CisPt. All of the above observations indicated that the cultivation of $\mathrm{S}$ cells in the presence of CisPt induced a more pronounced decrease in the Bcl-2 content when compared to R cells, which yielded a more effective formation of the Bax homodimer and as a consequence resulted in a larger proportion of cells that are able to undergo apoptosis in S cells. 


\section{Panel 1

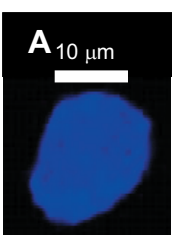

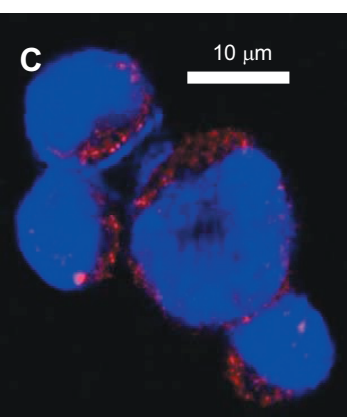

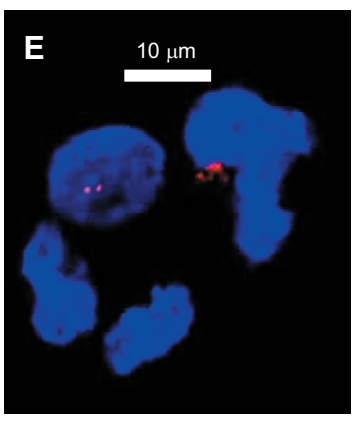

Panel 2
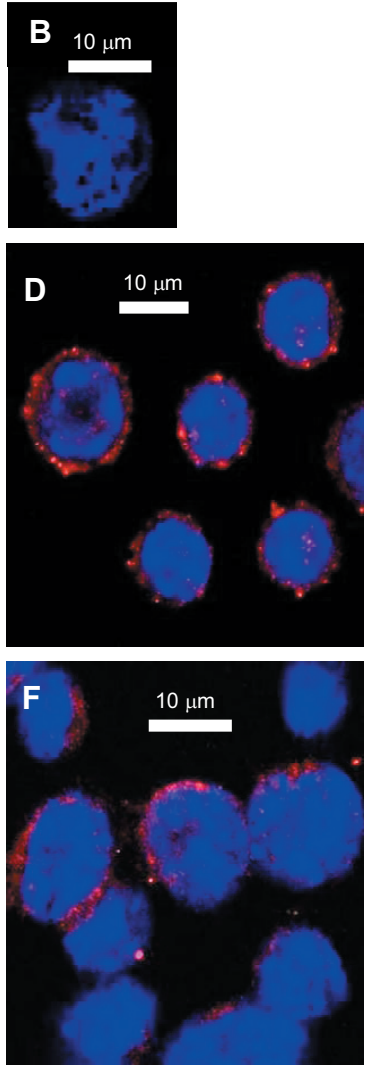

\section{Panel 3}
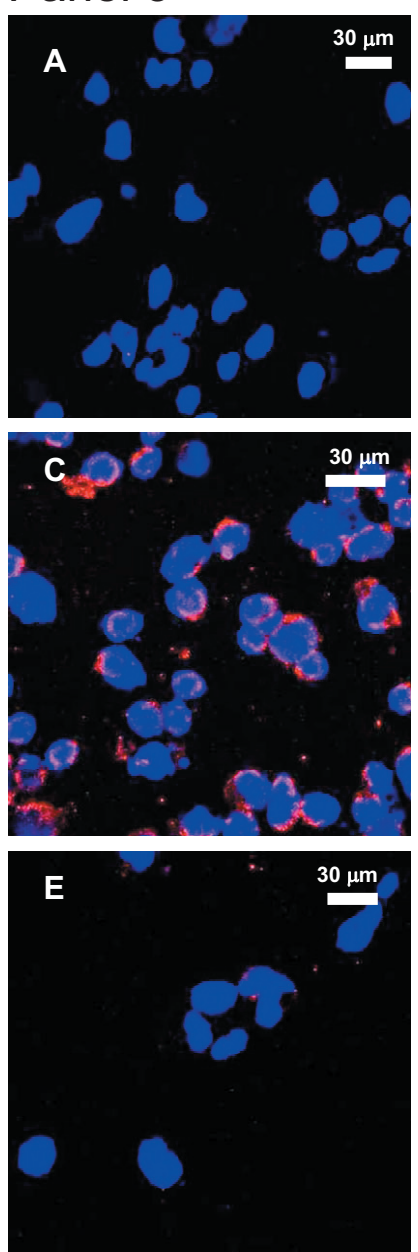

\section{Panel 4}
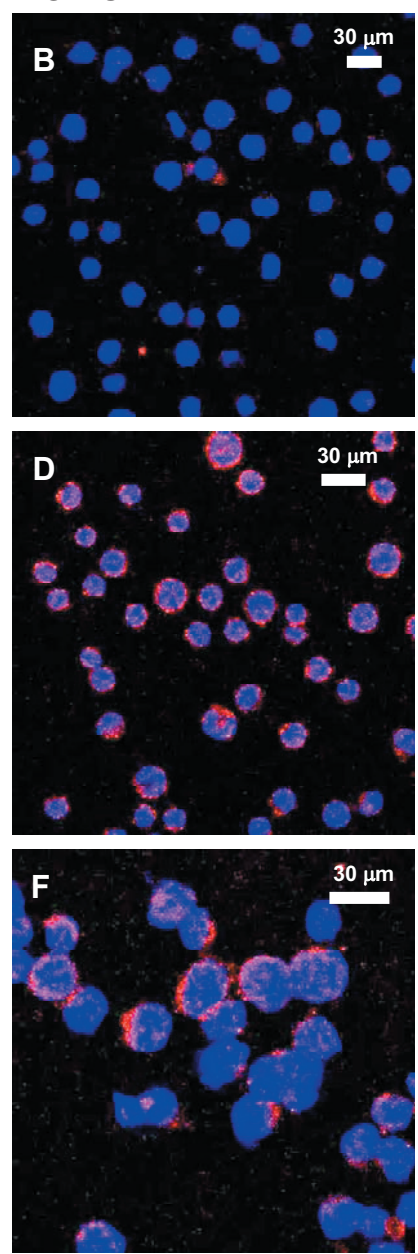

Figure 6. The visualization of the CisPt-induced effect on the content and localization of Bcl-2 in S (panel 1, 3) and R (panel 2, 4) cells. The cells were pre-incubated for $24 \mathrm{~h}$ with CisPt prior to immuno-staining. The cells were stained with anti-Bcl-2 antibody and with DAPI (index C, D, E, F). In control experiments, anti-Bcl-2 antibody was not applied (index A, B).

\section{CisPt-induced DNA fragmentation in $S, R$ and $V$ cells}

CisPt was previously reported to induce cell death by: i) a "classic" apoptotic mechanism as a result of CisPtinduced DNA damage that initiates the activation phase of apoptosis; ii) a defective apoptosis, which is a result of CisPt-induced protein damage that may activate caspases and thus initiate the executive phase of apoptosis; iii) necrosis (Gonzalez et al. 2001). Necrosis only plays a minor role in the CisPt-induced cell death effect in our experiments as demonstrated in Figs. 2 and 3. However, in order to prove that apoptosis is a dominant mechanism of the CisPt-induced cell death effect, we demonstrated DNA fragmentation that was typical for apoptosis in S, R and V cells after a $24 \mathrm{~h}$ period of incubation in the presence of CisPt $(10 \mathrm{mg} / \mathrm{l})$. We observed apoptotic DNA fragmentation in S, R and V cells after incubation in the presence of CisPt (Fig. 8). This proved that apoptosis was a dominant mechanism for the CisPt-induced cell death effect in our experiments. CisPt may induce this effect through the initiation of DNA damage or by protein damage that may induce cytochrome $c$ release from the mitochondria (Fig. 4) and by the activation of caspases, particularly caspase 3 . This caspase is known to be responsible for the cleavage of the DNA fragmentation factor that subsequently activates the DNA endonuclease (DFF40) that is required for the formation of apoptotic DNA ladders (Liu et al. 1998; Gonzalez et al. 2001). However, the question as to whether or not CisPt-induced apoptosis in our cells by DNA damage or by protein damage as primary stimulus will need to be addressed in future studies. 


\section{Immunoprecipitation with}

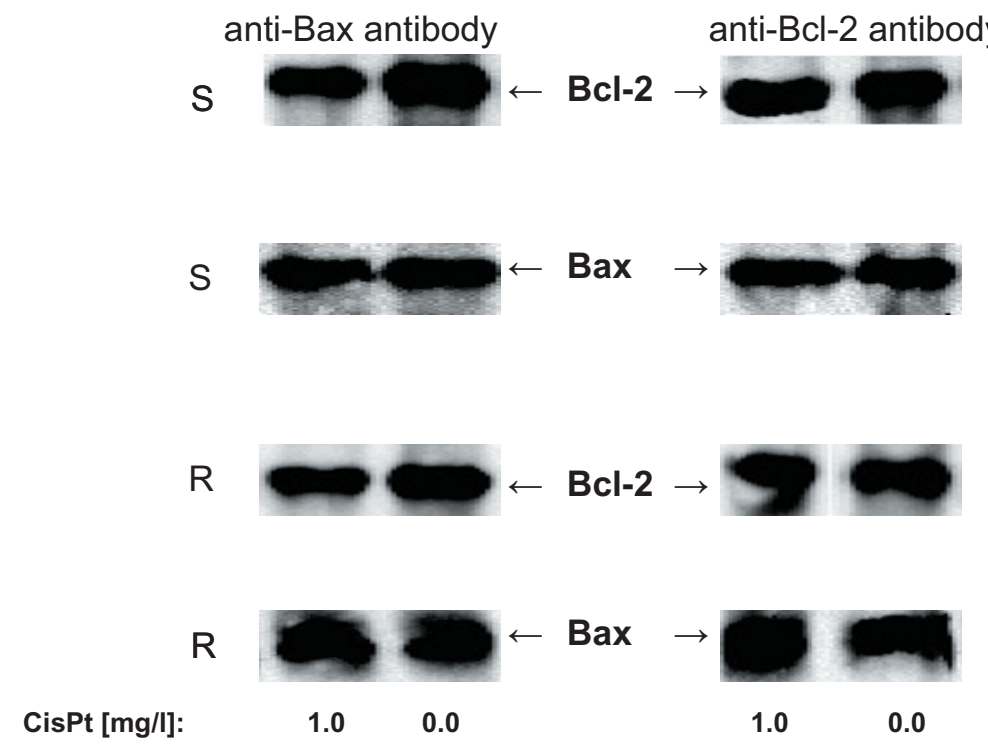

Figure 7. The effect of CisPt on the composition of the Bcl-2:Bax complex established by immuno-precipitation. These data represented typical results from three independent experiments. All details about experimental procedures are described in chapter Materials and Methods.

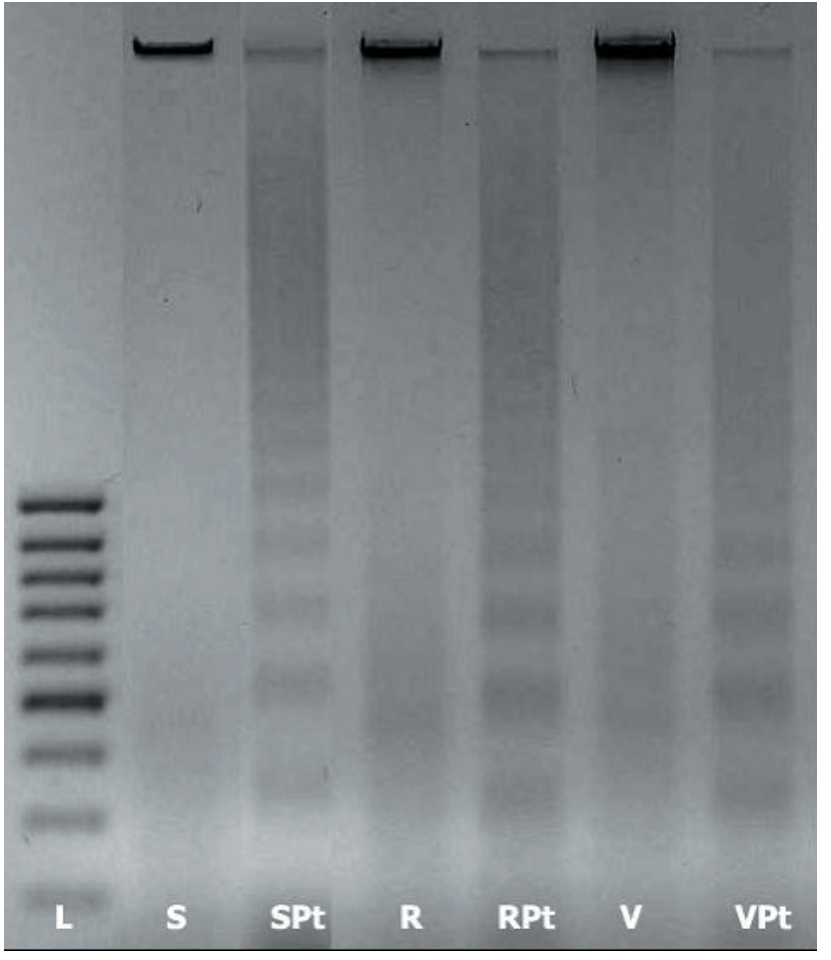

Figure 8. CisPt induced DNA fragmentation in cells. Cells were pre-incubated for $24 \mathrm{~h}$ without (S, R, V cells) or with $10 \mathrm{mg} / \mathrm{l} \mathrm{CisPt} \mathrm{(SPt,} \mathrm{RPt,}$ VPt cells). L, ladder was used as standard. These data represented typical results from three independent experiments. All details about experimental procedures are described in chapter Materials and Methods.

\section{Conclusion}

Multidrug resistant P-gp positive L1210/VCR cells are also resistant to CisPt. Resistance to CisPt is due to a mechanism that is distinct from P-gp drug efflux activity and is associated with a lower effect of CisPt on: i) the elevation of the cytochrome c concentration in the cytoplasm and ii) the decrease of anti-apoptotic $\mathrm{Bcl}-2$ protein content in L1210/VCR cells as compared with P-gp negative L1210 cells. The precise mechanisms of this phenomenon are still unknown but are in the process of being studied by our laboratory.

Acknowledgements. This research was supported in part by the following grants: from Slovak Research and Development Agency: APVV-0084-07, VVCE-0067-07; from Slovak Grant Agency for Science VEGA: 2/7122/27, 2/0155/09.

\section{References}

Barancik M., Polekova L., Mrazova T., Breier A., Stankovicova T., Slezak J. (1994): Reversal effects of several Ca(2+)-entry blockers, neuroleptics and local anaesthetics on P-glycoprotein-mediated vincristine resistance of L1210/VCR mouse leukaemic cell line. Drugs. Exp. Clin. Res. 20, 13-18

Barancik M., Bohacova V., Kvackajova J., Hudecova S., Krizanova O., Breier A. (2001): SB203580, a specific inhibitor of 
p38-MAPK pathway, is a new reversal agent of P-glycoprotein-mediated multidrug resistance. Eur. J. Pharm. Sci. 14, 29-36; doi:10.1016/S0928-0987(01)00139-7

Barancik M., Bohacova V., Sedlak J., Sulova Z., Breier A. (2006): LY294,002, a specific inhibitor of PI3K/Akt kinase pathway, antagonizes P-glycoprotein-mediated multidrug resistance. Eur. J. Pharm. Sci. 29, 426-434; doi:10.1016/ j.ejps.2006.08.006

Bohacova V., Kvackajova J., Barancik M., Drobna Z., Breier A. (2000): Glutathione S-transferase does not play a role in multidrug resistance of L1210/VCR cell line. Physiol. Res. 49, 447-453

Bohacova V., Sulova Z., Dovinova I., Polakova E., Barancik M., Uhrik B., Orlicky J., Breier A. (2006): L1210 cells cultivated under the selection pressure of doxorubicin or vincristine express common mechanisms of multidrug resistance based on the overexpression of P-glycoprotein. Toxicol. In Vitro 20, 1560-1568; doi:10.1016/j.tiv.2006.07.011

Breier A., Drobna Z., Docolomansky P., Barancik M. (2000): Cytotoxic activity of several unrelated drugs on L1210 mouse leukemic cell sublines with P-glycoprotein (PGP) mediated multidrug resistance (MDR) phenotype. A QSAR study. Neoplasma 47, 100-106

Breier A., Barancik M., Sulova Z., Uhrik B. (2005): P-glycoprotein--implications of metabolism of neoplastic cells and cancer therapy. Curr. Cancer Drug Targets 5, 457-468; doi:10.2174/1568009054863636

Brunelle J. K., Letai A. (2009): Control of mitochondrial apoptosis by the Bcl-2 family. J. Cell. Sci. 122, 437-441; doi:10.1242/ jcs.031682

Campos L., Oriol P., Sabido O., Guyotat D. (1997): Simultaneous expression of P-glycoprotein and BCL-2 in acute myeloid leukemia blast cells. Leuk. Lymphoma 27, 119-125

Chao C. C. (1996): Cross-resistance to cis-diamminedichloro platinum(II) of a multidrug-resistant lymphoma cell line associated with decreased drug accumulation and enhanced DNA repair. Eur. J. Pharmacol. 305, 213-222; doi:10.1016/0014-2999(96)00168-9

Cho H. J., Kim J. K., Kim K. D., Yoon H. K., Cho M. Y., Park Y. P., Jeon J. H., Lee E. S., Byun S. S., Lim H. M., Song E. Y., Lim J. S., Yoon D. Y., Lee H. G., Choe Y. K. (2006): Upregulation of Bcl-2 is associated with cisplatin-resistance via inhibition of Bax translocation in human bladder cancer cells. Cancer Lett. 237, 56-66; doi:10.1016/ j.canlet.2005.05.039

Cipak L., Rauko P., Miadokova E., Cipakova I., Novotny L. (2003): Effects of flavonoids on cisplatin-induced apoptosis of HL-60 and L1210 leukemia cells. Leuk. Res. 27, 65-72; doi:10.1016/S0145-2126(02)00063-2

Dave Z., Byfield M., Bossy-Wetzel E. (2008): Assessing mitochondrial outer membrane permeabilization during apoptosis. Methods 46, 319-323; doi:10.1016/j.ymeth.2008.10.019

Degli Esposti M., Dive C. (2003): Mitochondrial membrane permeabilisation by Bax/Bak. Biochem. Biophys. Res. Commun. 304, 455-461; doi:10.1016/S0006-291X(03)00617-X

Del Principe M. I., Del Poeta G., Maurillo L., Buccisano F., Venditti A., Tamburini A., Bruno A., Cox M. C., Suppo G., Tendas A., Gianni L., Postorino M., Masi M., Del Principe
D., Amadori S. (2003): P-glycoprotein and BCL-2 levels predict outcome in adult acute lymphoblastic leukaemia. Br. J. Haematol. 121, 730-738; doi:10.1046/j.13652141.2003.04343.x

Fiala R., Sulová Z., El-Saggan A. H., Uhrík B., Liptaj T., Dovinová I., Hanušovská E., Drobná Z., Barančík M., Breier A. (2003): P-glycoprotein-mediated multidrug resistance phenotype of L1210/VCR cells is associated with decreases of oligoand/or polysaccharide contents. Biochim. Biophys. Acta 1639, 213-224

Gerlier D., Thomasset N. (1986): Use of MTT colorimetric assay to measure cell activation. J. Immunol. Methods 94, 57-63; doi:10.1016/0022-1759(86)90215-2

Gonzalez V. M., Fuertes M. A., Alonso C., Perez J. M. (2001): Is cisplatin-induced cell death always produced by apoptosis? Mol. Pharmacol. 59, 657-663

Gross A., Jockel J., Wei M. C., Korsmeyer S. J. (1998): Enforced dimerization of BAX results in its translocation, mitochondrial dysfunction and apoptosis. EMBO J. 17, 3878-3885; doi:10.1093/emboj/17.14.3878

Hockenbery D. M., Zutter M., Hickey W., Nahm M., Korsmeyer S. J. (1991): BCL2 protein is topographically restricted in tissues characterized by apoptotic cell death. Proc. Natl. Acad. Sci. U. S. A. 88, 6961-6965; doi:10.1073/ pnas.88.16.6961

Kišucká J., Barančík M., Boháčová V., Breier A. (2001): Reversal effect of specific inhibitors of extracellular-signal regulated protein kinase pathway on P-glycoprotein mediated vincristine resistance of L1210 cells. Gen. Physiol. Biophys. 20, 439-444

Krishan A., Dandekar P. D. (2005): DAPI fluorescence in nuclei isolated from tumors. J. Histochem. Cytochem. 53, 1033-1036; doi:10.1369/jhc.4B6563.2005

Kupsáková I., Rybár A., Dočolomanský P., Drobná Z., Stein U., Walther W., Barančík M., Breier A. (2004): Reversal of P-glycoprotein mediated vincristine resistance of L1210/VCR cells by analogues of pentoxifylline. A QSAR study. Eur. J. Pharm. Sci. 21, 283-293; doi:10.1016/ j.ejps.2003.10.019

Laane E., Panaretakis T., Pokrovskaja K., Buentke E., Corcoran M., Soderhall S., Heyman M., Mazur J., Zhivotovsky B., Porwit A., Grander D. (2007): Dexamethasone-induced apoptosis in acute lymphoblastic leukemia involves differential regulation of Bcl-2 family members. Haematologica 92, 1460-1469; doi:10.3324/haematol.10543

Laemmli U. K. (1970): Cleavage of structural proteins during the assembly of the head of bacteriophage T4. Nature 227, 680-685; doi:10.1038/227680a0

Lessene G., Czabotar P. E., Colman P. M. (2008): BCL-2 family antagonists for cancer therapy. Nat. Rev. Drug. Discov. 7, 989-1000; doi:10.1038/nrd2658

Liu X., Li P., Widlak P., Zou H., Luo X., Garrard W. T., Wang X. (1998): The 40-kDa subunit of DNA fragmentation factor induces DNA fragmentation and chromatin condensation during apoptosis. Proc. Natl. Acad. Sci. U. S. A. 95, 8461-8466; doi:10.1073/pnas.95.15.8461

Marschitz I., Tinhofer I., Hittmair A., Egle A., Kos M., Greil R. (2000): Analysis of Bcl-2 protein expression in chronic 
lymphocytic leukemia. A comparison of three semiquantitation techniques. Am. J. Clin. Pathol. 113, 219-229; doi:10.1309/491W-L1TN-UFQX-T61B

Oltvai Z. N., Milliman C. L., Korsmeyer S. J. (1993): Bcl-2 heterodimerizes in vivo with a conserved homolog, Bax, that accelerates programmed cell death. Cell 74, 609-619; doi:10.1016/0092-8674(93)90509-O

Orlický J., Sulová Z., Dovinová I., Fiala R., Záhradniková A. Jr., Breier A. (2004): Functional fluo-3/AM assay on P-glycoprotein transport activity in L1210/VCR cells by confocal microscopy. Gen. Physiol. Biophys. 23, 357-366

Pauwels E. K., Erba P., Mariani G., Gomes C. M. (2007): Multidrug resistance in cancer: its mechanism and its modulation. Drug News Perspect. 20, 371-377; doi:10.1358/ dnp.2007.20.6.1141496

Poleková L., Barančík M., Mrázová T., Pirker R., Wallner J., Sulová Z., Breier A. (1992): Adaptation of mouse leukemia cells L1210 to vincristine. Evidence for expression of P-glycoprotein. Neoplasma 39, 73-77

Pop I., Pop L., Vitetta E. S., Ghetie M. A. (2008): Generation of multidrug resistant lymphoma cell lines stably expressing P-glycoprotein. Oncol. Rep. 19, 889-895

Ren L., Xiao L., Hu J. (2007): MDR1 and MDR3 genes and drug resistance to cisplatin of ovarian cancer cells. J. Huazhong Univ. Sci. Technolog. Med. Sci. 27, 721-724

Šereš M., Poláková E., Križanová O., Hudecová S., Klymenko S. V., Breier A., Sulová Z. (2008): Overexpression of P-glycoprotein in L1210/VCR cells is associated with changes in several endoplasmic reticulum proteins that may be partially responsible for the lack of thapsigargin sensitivity. Gen. Physiol. Biophys. 27, 211-221

Sorenson C. M., Barry M. A., Eastman A. (1990): Analysis of events associated with cell cycle arrest at 22 phase and cell death induced by cisplatin. J. Natl. Cancer Inst. 82, 749-755; doi:10.1093/jnci/82.9.749

Sulová Z., Orlický J., Fiala R., Dovinová I., Uhrík B., Šereš M., Gibalová L., Breier A. (2005): Expression of P-glycoprotein in L1210 cells is linked with rise in sensitivity to Ca2+. Biochem. Biophys. Res. Commun. 335, 777-784; doi:10.1016/j.bbrc.2005.07.144

Sulová Z., Macejová D., Šereš M., Sedlák J., Brtko J., Breier A. (2008): Combined treatment of P-gp positive L1210/VCR cells by verapamil and all-trans retinoic acid induces down-regulation of P-glycoprotein expression and transport activity. Toxicol. In Vitro 22, 96-105; doi:10.1016/ j.tiv.2007.08.011
Sulová Z., Mislovičová D., Gibalová L., Vajčnerová Z., Poláková E., Uhrík B., Tylková L., Kovárová A., Sedlák J., Breier A. (2009): Vincristine-induced overexpression of P-glycoprotein in L1210 cells is associated with remodeling of cell surface saccharides. J. Proteome Res. 8, 513-520; doi:10.1021/pr8007094

Tabe Y., Konopleva M., Contractor R., Munsell M., Schober W. D., Jin L., Tsutsumi-Ishii Y., Nagaoka I., Igari J., Andreeff M. (2006): Up-regulation of MDR1 and induction of doxorubicin resistance by histone deacetylase inhibitor depsipeptide (FK228) and ATRA in acute promyelocytic leukemia cells. Blood 107, 1546-1554; doi:10.1182/blood2004-10-4126

Takara K., Sakaeda T., Tanigawara Y., Nishiguchi K., Ohmoto N., Horinouchi M., Komada F., Ohnishi N., Yokoyama T., Okumura K. (2002): Effects of 12 Ca2+ antagonists on multidrug resistance, MDR1-mediated transport and MDR1 mRNA expression. Eur. J. Pharm. Sci. 16, 159-165; doi:10.1016/S0928-0987(02)00082-9

Takara K., Tsujimoto M., Kokufu M., Ohnishi N., Yokoyama T. (2003): Up-regulation of MDR1 function and expression by cisplatin in LLC-PK1 cells. Biol. Pharm. Bull. 26, 205-9; doi:10.1248/bpb.26.205

Towbin H., Staehelin T., Gordon J. (1979): Electrophoretic transfer of proteins from polyacrylamide gels to nitrocellulose sheets: procedure and some applications. Proc. Natl. Acad. Sci. U.S.A. 76, 4350-4354; doi:10.1073/ pnas.76.9.4350

Tsai S. Y., Sun N. K., Lu H. P., Cheng M. L., Chao C. C. (2007): Involvement of reactive oxygen species in multidrug resistance of a vincristine-selected lymphoblastoma. Cancer Sci. 98, 1206-1214; doi:10.1111/j.13497006.2007.00513.x

Yan X. D., Li M., Yuan Y., Mao N., Pan L. Y. (2007): Biological comparison of ovarian cancer resistant cell lines to cisplatin and Taxol by two different administrations. Oncol. Rep. 17, 1163-1169

Yang X., Page M. (1995): P-glycoprotein expression in ovarian cancer cell line following treatment with cisplatin. Oncol. Res. 7, 619-624

Zhou S. F. (2008): Structure, function and regulation of P-glycoprotein and its clinical relevance in drug disposition. Xenobiotica 38, 802-832; doi:10.1080/00498250701867889

Received: July 20, 2009

Final version accepted: September 17, 2009 